\title{
ACTUALIDAD LITERARIA HISPANOARGELINA (II): LA RECIENTE OBRA DE SOUAD HADJ-ALI MOUHOUB
}

\author{
IsAAC DonOso \\ Universidad de Alicante
}

Cronología de mi dolor por Argelia y otros relatos contra el olvido, El Ejido, Anubis, 2010, 118 pp. [ISBN: 978-84-937782-5-5]; Segunda edición: Madrid, DiwanMayrit, 2018, 117 pp. [ISBN: 978-84-948714-9-8]

El ritual de la boqala:poesía oral femenina argelina, Madrid, CantArabia, 2011, 98 pp. [IsBn: 978-84-86514-75-4]

Memorias calladas. Relatos, Madrid, CantArabia, 2017, 180 pp. [isbn: 978-84-86514-79-2]

En suelo argelino se escuchó hablar latín y árabe, al igual que en España. Ambas lenguas evolucionaron hacia variantes neolatinas y neoárabes, al igual que en España. Sin embargo, la secuencia histórica siguió de forma inversa; mientras el dialecto andalusí fue desarraigado de la península ibérica, el romance norteafricano desaparecía de tierras argelinas. De algún modo, y en las necesidades expresivas tanto de españoles como de argelinos, vivió y vive latente la presencia identitaria de esta ausencia: la lengua árabe para los españoles, y el romance para los argelinos. No obstante, el material que los hombres usan para comunicarse no desaparece de forma abrupta, no lo puede hacer. Si el sistema naufraga, al menos las palabras sí pueden sobrevivir, y así lo atestiguan los numerosos arabismos léxicos de los romances ibéricos. La lingua franca argelina fue igualmente un ejemplo de rehabilitación idiosincrática de una koiné neolatina, como el francés, en términos de Camus, entroncaba la modernidad de Argelia con su pasado mediterráneo.

Pero ha existido una relación fundacional de la nación argelina con otra variante neolatina, no sólo porque miles de mudéjares y moriscos españoles poblaron las ciudades y pueblos de la costa norteafricana desde 
el siglo Xıır, y la larga españolidad de las plazas de Orán y Mazalquivir, sino también por el hecho emblemático del lustro que Miguel de Cervantes vivió en Argel.

El castellano es una lengua extranjera en Argelia, pero posiblemente sea como ninguna otra lengua extranjera. Es por ello que su escritura, como lengua de expresión, no tenga por qué ser ajena al alma argelina, y es por ello que históricamente pueden encontrarse textos argelinos escritos en español desde hace varios siglos, al menos desde Ibrahim de Bolfad. Ciertamente no es abundante la cantidad de obras que pueden dar forma a un corpus de literatura hispanoargelina, y muchos textos pueden ser entendidos como ejercicios escolares o experiencias escriturarias esporádicas, pero también - y no podía ser de otro modo en un país cruce de caminos como Argelia- han de producirse acciones conscientes de expresión, en este caso, articulando con fines artísticos la lengua de Cervantes.

Éste posiblemente sea el caso de Souad Hadj-Ali Mouhoub, ciertamente uno de los casos más acabados, y en mejor disposición de consolidar una obra creativa sólida y literariamente valiosa. Hadj-Ali ha demostrado en los últimos años un excelente dominio de la lengua, con una prosa elegante, poco dada a los artificios insustanciales, y contundente en la sucesión de hechos. Autora sobre todo de cuentos, sus textos, con la extensión justa, ubican al lector en la escena de forma inmediata. Así puede verse en el comienzo de "La desconocida de la Casa de Campo" (20IO):

Rosa era una chica joven. Aparentaba tener veinticuatro años, pero sus ojos tenian una expresión ingenua, reflejaban la inocencia de una persona que añora la infancia y todavía no ha salido de la adolescencia. No era alta. No tenía la estatura de la bella rubia polaca de la calle Montera que se imponía por su alteza y buen plante; no, era más bien menuda. Aunque tenia las piernas más gruesas que el resto del cuerpo, esa desproporción no afeaba su talle fino y pecho delicado. Su largo cabello de rizos negros que le llegaba a la cintura, enmarcaba un rostro de delicados rasgos en el que resaltaban grandes ojos color canela salpicados de verde primaveral. Sus ojos en forma de almendra, cuyos contornos estaban reforzados con el marrón oscuro de rimel, ensombrecian aún más su piel eternamente bronceada. 
Hadj-Ali nace en 1955 en la ciudad de Bordj Bou Arréridj, bella localidad de provincias con un importante centro histórico de la época francesa. Después de terminar los estudios, fue profesora de lengua española en la Universidad de Argel desde 1982 a 1993. Los acontecimientos que se sucedieron a comienzos de esa década hicieron forzosa la salida del país, primero en un exilio apresurado hacia Túnez, y después con un permiso de residencia en España a partir de 1995. Vecina de Madrid desde entonces, Hadj-Ali ha ejercido activamente de madrileña, involucrándose en las actividades de la ciudad, pero también fomentando el mayor conocimiento de la cultura argelina, por ejemplo a través de la asociación «Presencia Argelina». Han sido muchas las actividades que se han realizado desde esta plataforma, tanto conferencias como documentos impresos, entre otros el cuaderno Palabras. Versos y prosa de mujeres argelinas (2004).

Con una inicial trayectoria realizando texto en francés para publicaciones como Atelier de Recherche sur la Femme Algérienne y AlgérieLittératurel Action, las trágicas consecuencias de la década negra marcaron el devenir de Souad Hadj-Ali. Forzada a abandonar el país, su memoria quedará ligada al sufrimiento de sus compatriotas, a la dignidad de los muertos por ser, al menos, recordados. Éste es el espíritu que vertebra Cronología de mi dolor por Argelia y otros relatos contra el olvido, desgarrador y duro testimonio de las consecuencias humanas del conflicto civil. Pero más que un testimonio - a pesar de contener indudables elementos autobiográficos-, los diferentes relatos y cuentos que se suceden en este libro construyen un mundo literario de personajes que vagan, que arrastran sus vidas a través de la hostilidad. En este sentido puede destacarse uno de los cuentos más valiosos de la colección, ciertamente estremecedor, "Éramos cinco":

Éramos cinco amigas desenvueltas y gallardas. Bellas, alegres y vivas. Intransigentes con la vida. Exigiamos de ella salud, amor y riqueza, pero lo que más anhelábamos era libertad. La mayor de nosotras no alcanzaba los diecisiete años, la menor tenía apenas quince. Viviamos en un pueblo de la periferia, a unos 20 kilómetros al sur de Argel. Todas en el mismo barrio [...] No supimos más de Katia hasta que un día, saliendo de su casa, nos esperaba una furgoneta en el garaje. Cuatro hombres encapuchados actuaban bajo las órdenes de Hicham. Nos taparon la boca y los ojos y nos ataron de pies y manos [...] Nos dio unas sobras de la cena y nos indicó dónde teníamos que dormir. 
A ella le tocaba estar con su marido, en otra habitación. Su hermano Hicham fue testigo de su matrimonio con el jefe de la zona. Nos comentó que no sufría malos tratos por ser la hermana de uno de ellos, pero se quejó de la cantidad de trabajo que le caía encima. Tenía que administrarlo todo, preparar las comidas, lavar la ropa de los militantes, satisfacer a su bestia de marido cuantas veces se lo pidiese, pese a su embarazo. Ella lo que quería era abortar, pero no habia manera. Alli estaba agarrado el feto. Las demás, las que iban llegando, padecían lo peor que podía sufrir una persona humana y, cuando se quedaban embarazadas, las mataban o las abandonaban a la intemperie y en plena montaña. Yo sabia que algunas conseguian volver a sus casas. Otras eran rechazadas por sus propios padres porque llevaban en sí el mal y la impureza.

La capacidad de atenerse a lo esencial, con los epítetos justos y una narración que reclama empatía al lector, conducen hacia una obra de sobria factura, muy alejada del tremendismo que se podría esperar por la gravedad de la materia tratada. Más allá del valor testimonial, el interés literario del cuento ha merecido su difusión a través de colecciones y antologías, en el libro de Gloria Serrato Azat (ed.), De raiz, creaciones de mujeres del mundo, Madrid, Horas y Horas, 2003, y en la «Biblioteca Africana», Cronología de mi dolor por Argelia y otros relatos contra el olvido [selección de fragmentos], edición de Enrique Lomas López, Alicante, Biblioteca Virtual Miguel de Cervantes, 20I2: < $\underline{\text { http://www.cervantes- }}$ virtual.com/nd/ark:/5985I/bmcgo2so >.

También es significativo el cuento "Azaroso Miloud" que narra, a través de una alegoría surrealista, uno de los episodios que más conmocionaron a la opinión pública española a mediados de los noventa. La historia oficial cuenta que el joven indocumentado argelino Miloud Khedari defendió a una mujer de ser agredida en el metro de Madrid, lo que le costó ser arrollado por el tren perdiendo una pierna y el ojo izquierdo. Souad Hadj-Ali recupera literariamente este impactante acontecimiento para llevarlo más allá del sensacionalismo que causó en una sociedad incrédula por lo que estaba pasando en Argelia durante esa década, e ignorante del sufrimiento de los argelinos que huían de su país. Con una alegoría escatológica más cercana a Buñuel que a Rulfo, HadjAli sorprende con un procedimiento literario que dignifica la figura de Miloud y, al mismo tiempo, denuncia el papel aciago al que la hostilidad social condena a los inmigrantes. 
La capacidad narrativa que la autora había demostrado en esta primera colección de relatos se refrenda en Memorias calladas, obra de 2017 que aparece en la prestigiosa editorial CantArabia. Se trata de una extensa colección de cuentos cuya temática ya no es necesariamente argelina. Hadj-Ali sutura el pasado bélico e inmigrante y, como ciudadana de Madrid, plantea temáticas intrínsecas al nuevo contexto escriturario. Sin duda mucha de su cuentística girará en torno a la mujer y a la percepción femenina de la realidad, pero no es sólo ese el tipo de literatura producida recientemente por la autora argelina. De forma consciente, Hadj-Ali intenta ir más allá del cliché de escritora inmigrante que, estereotipada y fácilmente, se le podría atribuir. Su obra ofrece mayor polifonía de la que aparentemente podría intuirse y, al igual que Cronología de mi dolor por Argelia es mucho más que un relato autobiográfico, Memorias calladas no es ni mucho menos un alegato feminista. Si el primer volumen ofrece a la literatura en lengua española una obra excepcional que bien merece per se dar carta fundacional a una 'literatura hispanoargelina', Memorias calladas expande la posible recepción de esta literatura a un público amplio, a un público no sólo, no necesariamente, interesado por la materia específica. De este modo Hadj-Ali se nos presenta como una excelente prosista, cuyo público receptor son quinientos millones de hispanohablantes.

Lo cierto es que su labor en la consolidación de unas letras argelinas en castellano se refuerza con la difusión de importantes referentes de la cultura de Argelia, tal el caso de Rachid Boudjedra y la traducción de L'Escargot entêté (1977: El caracol obstinado, 2012). También a través de la investigación en el patrimonio oral e inmaterial y la publicación de trabajos que ofrezcan un acercamiento más íntimo a la cultura argelina. En concreto, recopila y edita un material transmitido por Djamila Menacer Abdi (la recitadora) y Menouba M. Hadj Amar. Se trata de la poesía popular producida en árabe argelino que se recita en El ritual de la boqala: poesía oral femenina argelina, obra de singular valía al permitir que el lector en español pueda conocer un verdadero tesoro lingüístico, literario y cultural del alma argelina. Si no fuera suficiente, el texto publicado por CantArabia se acompaña de numerosos y bellísimas ilustraciones realizadas por Idriss Mouhoub, que hacen del volumen una lectura deliciosa. 
Con todo, nos encontramos ante un ejercicio aislado, y completamente voluntarioso, por producir una obra consciente en lengua española. Nadie le ha pedido a Souad Hadj-Ali que escriba; lo hace — así lo demuestra su trayectoria - por la necesidad personal de expresión, por la necesidad de dar a conocer la tragedia de la década negra, para suturar la herida emocional y rehabilitar un mundo, un mundo argelino íntimo y afectivo, con la afección que la lengua española tiene para la historia de Argelia. Siendo un ejercicio producido por la mera voluntad de su escritora, su recepción no es artificial o azarosa, esto es, a pesar de no tener un público definido, la autora sabe perfectamente crear interés por el mensaje que cuenta, más allá de lo que podría llamarse 'literatura de la inmigración'. Tampoco es un mero ejercicio voluntarioso, aventurarse en el oficio de escribir. Hadj-Ali conoce perfectamente el oficio, y domina con elegante maestría el principal instrumento, la lengua, pero no es el oficio lo que le interesa - así lo demuestra su escritura-, le interesa, como a los verdaderos autores, dar a conocer un mundo cuyo conocimiento es imperativo para que los hombres no olviden su propia humanidad. Y eso es lo que hacen, lo que deben hacer, los hombres y mujeres de letras: dar dignidad, al ser humano, a través de la palabra. Con Souad Hadj-Ali la lengua española gana un gran valor.

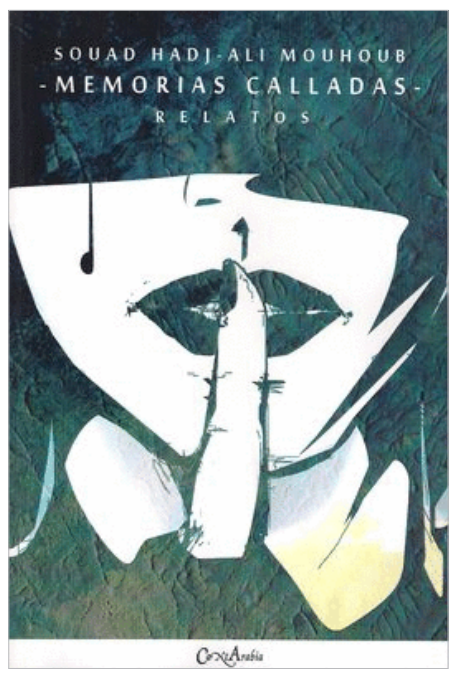




\section{Souad Hadj-Ali Mouhoub}
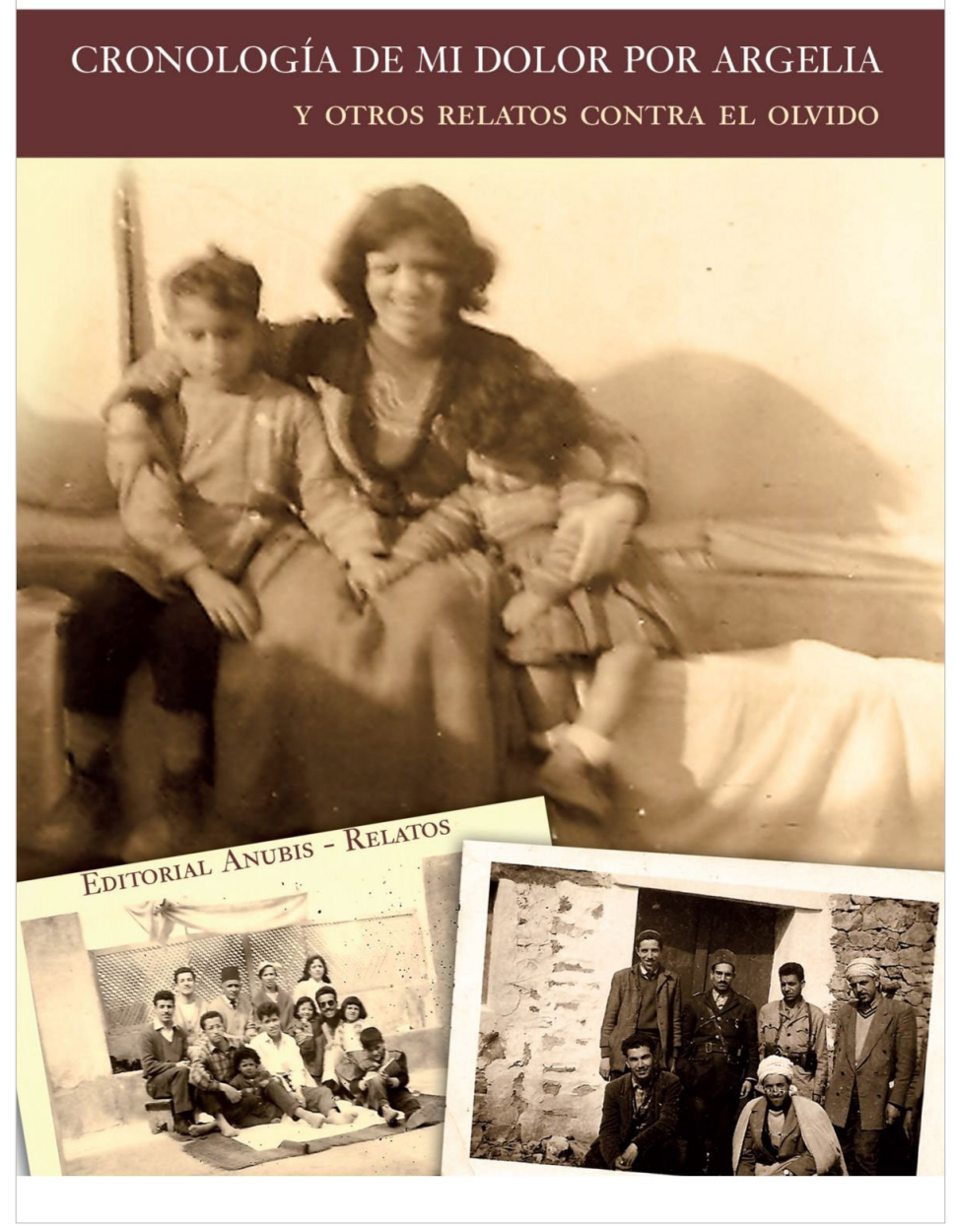
138 IsAac Donoso

\section{El ritual de la boqala Poesía oral femenina argelina}

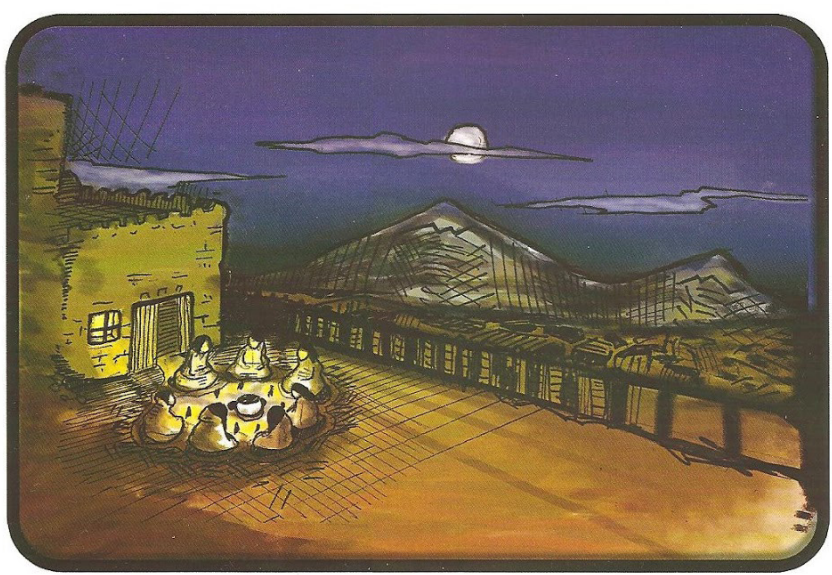

Edición al cuidado de Souad Hadj-Ali Mouhoub
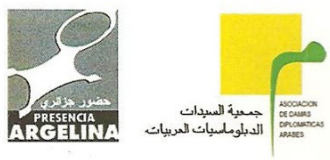

Carte Arabia 